\title{
Pengembangan Multimedia Pembelajaran Geografi dengan Materi Litosfer dan Pedosfer untuk SMA Kelas X
}

\author{
ANITA DESI KUSUMANINGTYAS DAN MUKMINAN \\ MTs Sunan Pandanaran \\ e-mail: needt4cubby@gmail.com
}

\begin{abstract}
Abstrak
Penelitian ini bertujuan menghasilkan produk multimedia pembelajaran yang layak dan efektif untuk meningkatkan hasil belajar siswa. Penelitian ini merupakan penelitian dan pengembangan, melalui analisis kebutuhan, desain pengembangan, pengembangan multimedia, dan validasi/evaluasi produk. Subjek penelitiannya 35 orang, yaitu dari one to one evaluation tiga orang, small group evaluation 12 orang, field trial 20 orang. Data penelitian dikumpulkan menggunakan instrumen yang berupa rating scale (1-5) dan tes hasil belajar (1-100). Data dianalisis menggunakan statistik deskriptif. Hasil penelitian menunjukkan produk layak digunakan. Ahli materi dan media memerikan nilai baik pada produk. Hasil uji coba satu-satu menunjukkan nilai rerata sebesar 3,63 (baik). Uji coba small group evaluation menghasilkan nilai rerata sebesar 3,87 (baik). Uji coba field trial menunjukkan nilai rerata sebesar 3,56 (baik). Rerata skor posttest siswa adalah 88,50, meningkat 6,75 dari rerata skor pretest 78,75. Kesimpulannya, media ini efektif digunakan untuk pembelajaran.
\end{abstract}

Kata Kunci: multimedia, pembelajaran geografi, litosfer dan pedosfer

\begin{abstract}
This research aims to produce appropriate and effecive instructional multimedia to improve the students' achievement. This research is a research and development which was performed through needs analysis, development design, multimedia development, and product validation/evaluation. The research subjects are 35 people consisting of three students in the one-to-one evaluation, 12 students in the small group evaluation, and 20 students in the field trial evaluation. The data were collected using the instrument in the form of rating scale (1-5) and learning achievement test (1100). The data were analyzed using descriptive statistics. The findings of the research show that Instructional multimedia is considered appropriate and effective as learning resources. Material and media experts state that the product has good criteria. The one to one evaluation shows a mean score of 3.63 (good). The small group evaluation shows a mean score of 3.87 (good). The field trial evaluation shows a mean score of 3.56 (good). The average post-test score of students is 88.50.It increases 6.75 of the average pre-test score 78.75. In conclusion, the developed geography instructional multimedia can be used effectively.
\end{abstract}

Keywords: multimedia, geography instructional, lithosfer and pedhosfer 


\section{PENDAHULUAN}

Berdasarkan paaradigma baru, proses pembelajaran menuntut peran aktif siswa untuk berinteraksi langsung dengan sumber pembelajaran. Guru tidak lagi berperan sebagai satu-satunya sumber informasi bagi kegiatan belajar siswa, karena peran guru saat ini lebih dititik beratkan sebagai perancang, fasilitator, kolabolator, dan evaluator.

Seiring tuntutan perkembangan jaman serta kemajuan ilmu dan teknologi (IPTEK), agar pembelajaran berjalan efektif, seyogyanya guru selalu menggunakan cara-cara kreatif dalam menyampaikan materi pembelajaran. Guru juga harus kreatif dan menguasai dalam penggunaan aneka strategi, metode, dan media pembelajaran. Dengan pesatnya perkembangan media informasi dan komunikasi telah mengakibatkan dampak bagi dunia pendidikan. Agar keaktifan siswa meningkat dan proses pembelajaran semakin efektif, maka salah satu alat bantu pembelajaran yang dapat diguna kan adalah komputer. Komputer mampu menampilkan berbagai jenis media se perti video, gambar, teks, animasi, dan suara sehingga dapat merangsang lebih banyak indera sehingga dapat menarik perhatian siswa untuk belajar.

Media komputer mampu menampilkan unsur audio-visual yang bermanfaat untuk meningkatkan minat belajar siswa. Bentuk interaksi yang dapat diaplikasikan adalah penyampaian informasi, praktek dan latihan, tutorial, permainan, simulasi, penemuan, dan pemecahan masalah. Kemajuan media komputer memberikan beberapa kelebihan untuk ke-giatan produksi audio-visual.

Multimedia pembelajaran merupa kan media yang dapat digunakan untuk menyalurkan pesan (pengetahuan, kete rampilan, dan sikap) serta dapat merangsang pikiran, perasaan, perhatian, dan kemampuan belajar sehingga secara sengaja proses belajar terjadi, bertujuan dan terkendali. Multimedia pembelajaran sangat bermanfaat untuk memudahkan siswa dalam belajar sehingga proses pembelajaran lebih interaktif, efektif, dan menarik atau menyenangkan sehingga kualitas belajar siswa meningkat.
Dukungan multimedia dalam proses pembelajaran diharapkan dapat meningkatkan kualitas hasil belajar siswa. Penggunaan multimedia pembelajaran juga dapat memungkinkan siswa untuk belajar secara mandiri. Untuk mendukung hal tersebut, penggunaan multimedia sangat diperlukan untuk menyampaikan dan memperjelas konsep yang ada serta membantu guru dalam menyampaikan materi pembelajaran kepada siswa.

Pada pembelajaran Geografi SMA khususnya materi litosfer dan pedosfer merupakan materi yang sangat banyak sedangkan jumlah jam yang ada sangat kurang untuk geografi kelas X hanya satu jam pelajaran. Di pihak guru, guru merasa kesulitan untuk menjelaskan kepada siswa karena siswa menginginkan gambar yang kongkrit untuk memudahan pemahaman. Selain itu masih terdapat beberapa masalah antara lain, yaitu: keaktifan belajar siswa dalam pembelajaran Geografi masih kurang, belum adanya bahan ajar Geografi berbasis multimedia, kalaupun ada belum dimanfaatkan secara maksimal. Media Pembelajaran yang ada kurang menarik bagi siswa, belum semua siswa memiliki buku teks Geografi, masih kurangnya kemampuan guru Geografi dalam menciptakan media pembelajaran berbasis komputer yang menarik bagi siswa, sehingga media pembelajaran yang ada menjadi kurang variatif.

Multimedia pembelajaran merupakan media yang dapat digunakan untuk menyalurkan pesan (pengetahuan, ketrampilan, dan sikap) serta dapat merangsang pikiran, perasaan, perhatian, dan kemampuan belajar sehingga secara sengaja proses belajar terjadi, bertujuan dan terkendali. Multimedia pembelajaran sangat bermanfaat untuk memudahkan siswa dalam belajar sehingga proses pembelajaran lebih interaktif, efektif, dan menarik atau menyenangkan sehingga kualitas belajar siswa meningkat.

Setelah melihat dan mencermati permasalahan-permasalahan yang terjadi di lapa ngan, maka peneliti merasa perlu untuk mencari solusinya agar pembelajaran geografi menjadi lebih menarik, menyenangkan, dan efektif, dengan mengembangkan multimedia 
pembelajaran interaktif yang dikemas dalam bentuk Compact Disk (CD) interaktif.

Penelitian yang dilakukan oleh Wagiran (2008), menunjukkan bahwa kualitas dan tampilan media yang bagus mendukung perkuliahan metrologi sehingga hasil belajar siswa bagus. Oleh karena itu, Media hasil pengembangan tersebut layak digunakan dalam pembelajaran.

Unik Ambarwati (2010) menunjukkan bahwa penelitian dan pengembangan dapat dilakukan melalui tiga tahap yaitu, analisis kebutuhan, pengembangan produk dan uji coba lapangan. Desain dirancang untuk mengakomodasi perbedaan gaya belajar sehingga dapat digunakan untuk mempermudahkan mahasiswa belajar secara mandiri. Tampilan visual yang disajikan mampu memotivasi mahasiswa, soal evaluasi yang bertingkat memberikan tantangan tersendiri bagi mahasiswa untuk senantiasa mencoba sampai berhasil ke level selanjutnya sehingga mampu menigkatkan retensi belajar mahasiswa secara tidak langsung. Multimedia dikembangkan berpedoman pada konsep teori kognitif.

\section{Pembelajaran Geografi}

Geografi berasal dari bahasa Yunani, yaitu geo yang berarti bumi dan graphein yang berarti lukisan atau tulisan. Oleh karena itu secara harfiah, geografi berarti lukisan tentang bumi. Sedangkan menurut pakar geografi pada seminar dan Lokakarya (Semlok) peningkatan kualitas pengajaran geografi di Semarang, geografi diartikan sebagai ilmu yang mempelajari persamaan dan perbedaan fenomena geosfer dengan sudut pandang kelingkungan, kewilayahan, dalam konteks keruangan. Dari pengertian diatas bahwa objek studi geografi geosfer atau lapisan permukaan bumi yang meliputi : lapisan udara yang menyelebungi bumi (atmosfer), lapisan batuan penyusun kerak bumi (litosfer), lapisan perairan (hidrosfer), lapisan makhluk hidup (biosfer), dan lapisan yang ditempati manusia (anthroposfer).

Eratosthenes dalam (Sumaatmadja, 1988, p.30) menyatakan bahwa geografi ber asal dari kata geographika yang berarti tu- lisan tentang bumi, yang diartikan bumi pada pengertian geografi tidak hanya berkenan dengan fisik alamiah bumi saja, melainkan juga meliputi segala gejala dan prosesnya, baik gejala dan proses alamnya, maupun gejala dan proses kehidupannya, bahwa terdapat hubungan antara gejala alam dengan manusia. Hal tersebut ditegaskan melalui pernyataan dari Barlet \& Cox (1982, p.2),

"Geography is a rather complex subject that emphasizes man-land relationship and involves the use of content drawn from geomorphology, climathology, biotic resources, and human geography, especially economic geography and settlement studies".

Kemudian menurut Ritter (Sumaatmaja, 1988, p.31) bahwa geografi mengkaji bumi sebagai tempat tinggal manusia. Pengertian bumi sebagai tempat tinggal manusia, tercakup di dalamnya segala kegiatan manusia berkenaan dengan organisasi, struktur, dan pola keruangan. Manusia selalu mencoba beradaptasi dengan lingkungan tempat tinggalnya, hal tersebut dilakukan untuk mempertahankan kelangsungan hidupnya. Pengertian diatas hampir sama intinya dengan pendapat dari William yang menyatakan bahwa geografi berkaitan dengan kenyataan yang dialami seseorang dalam perjalanan hidupnya dipermukaan bumi, yang dapat dihayati sebagai kesatuan dari faktor-faktor alam yang dimodifikasi, diubah, diadaptasi oleh tindakan manusia, hal tersebut disampaikan William dengan pernyataan berikut,

"Geography then deals with the real world, the world of which one learns best through one's boot sole or bare feet, or by main of trains, vessels, motor cars or aeroplanes, and only as make shifts by description, pictorial or otherwise. This involves relation with the natural science. It deals with the way in which this material world has influenced man, and in turn has been modified, altered and adapted by human action" (William, 1976, p.16).

Kemudian Preston E. James mencoba 
mengungkap bahwa konsep-konsep dalam geografi digunakan untuk mengkaji kondisi, masalah yang terjadi di berbagai tempat di bumi serta membantu dalam menemukan solusi dari masalah sosial yang ada. Hal tersebut disampaikan dengan pernyataan berikut,

"Geographic concepts are used to illuminate the conditions and problems of particular places on the earth for such practical purposes as making a living, or seeking the solution of social problems" (Ball, et al., 1971, p.3).

Berdasarkan beberapa pendapat di atas dapat disimpulkan, bahwa geografi adalah ilmu yang mempelajari fenomena yang terjadi di permukaan bumi (geosfer) dan interaksi anatara manusia dengan lingkungan tempat tinggalnya, serta mencoba memberi jawaban proses terjadinya fenomena, maupun memberikan solusi atas masalah yang muncul akibat fenomena yang terjadi dimuka bumi. agar guru sukses mengajar geografi, materi harus dikaitkan dengan kejadian nyata.

\section{LITOSFER DAN PEDOSFER}

\section{Litosfer}

Litosfer atau lapisan kerak bumi (earth's crust) merupakan lapisan tanah berbatu. Lapisan ini terdiri atas katamorfik dan metamorfik. Susunan unsur-unsur kimia yang terdapat pada lapisan kerak bumi diuraikan berdasarkan analisis terhadap barang-barang tambang (mineral) dan batu -batuan. Mineral-mineral tersebut merupakan komponen-komponen lapisan tanah atau batu-batuan yang membentuk lapisan kerak bumi. Menurut Lange (1991,pp.56-57) litosfer mengandung unsur oksigen $(46,8 \%)$, silikon (26\%), alumunium $(7,45 \%)$, Natrium $(2,40 \%)$, hirogen $(1 \%)$, Ferrum $(4,20 \%)$, Kalsium (3,25\%), Magnesium (2,35\%),dan Kalium sebesar 2,25\%.

\section{Pedosfer}

Pedosfer merupakan lapisan tanah, pembentukan tanah dipengaruhi oleh batuan induk, iklim, vegetasi, topografi dan waktu (usia lapisan tanah). Tanah terbentuk seba gai akibat dari pelapukan fisika, kimia, dan biologi yang komplek

Secara umum jenis lapisan tanah terhampar dipermukaan bumi sesuai dengan wilayah iklimnya. Jenis tanah tersebut meliputi: Tundra (padang rumput), Podzol, Hutan gelap (tanah hujau), Tanah hitam (chernozem), Tanah chestnut, tanah kering coklat padang rumput yang luas tanpa pohon, Padang pasir (abu-abu), Tanah alkali putih dan tanah saline (mengandung garam), dan Laterit (Darmawijaya, 1992, p.237).

\section{Karakteristik Siswa SMA}

Karakteristik siswa SMA adalah keseluruhan kelakuan dan kemapuan yang ada pada siswa sebagai hasil dari pembawaan dan lingkungan sosialnya sehingga menentukan pola aktivitas dalam meraih cita-citanya. Dengan demikian, penentuan tujuan belajar itu sebenarnya harus dikaitkan atau disesuaikan dengan keadaan atau karakteristik siswa itu sendiri. (Sardiman, A.M, 2011, p.120). Kemudian pengertian lain karakteristik siswa menurut Uno (2011, p.20) adalah aspek-aspek atau kualitas perorangan siswa seperti bakat, minat, motivasi, dan hasil belajar yang telah dimilikinya.

Karakteristik siswa menurut Oemar Hamalik (2004, pp.118-119) remaja memiliki beberapa kebutuhan dasar antara lain: kebutuhan umum manusia, kebutuhan akan identitas, dan kebutuhan akan bantuan orang dewasa. Kebutuhan umum manusia antara lain, kebutuhan untuk mencintai dan dicintai, ingin memiliki pengalaman-pengalaman baru, ingin memperoleh pengenalan atau pengakuan, ingin menjadi orang yang berdiri-sendiri, dan ingin memuaskan kebutuhan jasmaniah. Kemudian kebutuhan akan identitas antara lain: ingin memiliki suatu benda, ingin dikenal, ingin merasakan kehadirannya. Kemudian kebutuhan akan bantuan orang dewasa misalnya membutuhkan nasihat serta bimbingan dan penyuluhan orang dewasa.

Selain pendapat para ahli diatas, menurut Santrock (Budiningsih, 2005, p.39) dijelaskan bahwa karakteristik anak umur 12-18 (formal operation) anak sudah mampu me 
nganalisis secara kombinasi, dan merumuskan beberapa kemungkinan dari beberapa kemungkinan penyebabnya. Karakteristik seorang remaja yang lain adalah bahwa remaja selalu mendambakan terbebas dari dominasi orang dewasa, terutama orang tua. Atau dengan kata lain hal yang sangat penting bagi para remaja adalah otonomi (Hamalik, 2004, p.120). Berikut ini cara mempermudah belajar remaja antara lain adalah:

Belajar para remaja akan dipermudah apabila ada keseimbangan antara pembatasan dan kebebasan, (2) Belajar di sekolah akan dipermudah apabila para remaja diperlukan sebagai pribadi dan bukan sebagai benda, (3) Belajar akan dipermudah apabila para remaja tahu bahwa suaranya didengar dan pilihannya sungguh-sungguh diperhitungkan, (4) Belajar akan dipermudah apabila seseorang tahu bahwa ia diterima, dikenal, ataupun diakui oleh kelompoknya, dan kehadirannya menimbulkan perbedaan tertentu, (5) Belajar akan dipermudah serta perkembangan kepribadian yang seimbang akan meningkat apabila personal sekolah megenal berbagai integritas atau berbagai gaya belajar, (6) Belajar akan dipermudah apabila kapasitas para pemuda untuk mempercayai dirinya diterima dan mereka diberi semangat, (7) Mempelajari konsep-konsep yang terpilih dan konsep diri yang sehat akan dipermudah bila para remaja memahami dirinya sendiri dan kebudayaan remaja, (9) Lingkungan belajar akan menjadi baik bagi para remaja apabila guru mengetahui dan menerima beban dan tantangan terhadap dirinya sebagai pusat perhatian remaja sebagai model.

Terkait dengan penelitian ini, dengan mengetahui karakteristik siswa, akan sangat bermanfaat bagi guru dalam interaksi dalam proses belajar-mengajar agar lebih bermakna. Terutama bagi guru akan dapat merekonstruksi dan mengorganisasi materi pelajaran sedemikian rupa, memilih dan menentukan model pembelajaran yang lebih tepat, sehingga akan tercipta proses interaksi dari masing-masing komponen belajar me ngajar secara optimal.

Sudah dijelaskan diatas bahwa karakteris tik anak SMA (remaja) memiliki kecenderungan dan mendambakan agar terbebas dari dominasi orang dewasa. Hal ini jelas membuat guru merasa tertantang untuk selalu kreatif dalam menciptakan model pembelajaran yang bervariasi, model pembelajaran yang membuat siswa lebih semangat untuk belajar, sehingga guru mampu mengantarkan siswa sesuai dengan tujuan pembelajaran.

\section{Pengertian Multimedia}

Pengertian tentang multimedia yang merupakan perkembangan lebih lanjut dari media audiovisual dikemukakan oleh bebe rapa ahli. Di antaranya Mayer (2009: 3), yang berpendapat bahwa secara umum multimedia diartikan sebagai presensi materi dengan menggunakan kata-kata sekaligus gambargambar. Maksud dari 'kata' disini adalah materinya disajikan dalam bentuk verbal misalnya menggunakan teks kata-kata yang tercetak atau terucapkan (narasi). Maksud 'gambar' adalah materinya materinya disajikan dalam bentuk gambar baik itu gambar statis (foto, peta, grafik) maupun peta dinamis (animasi,video).

Latuheru (1988, p.81), mengatakan bahwa multimedia meliputi keseluruhan dari bentuk media yang digunakan dalam suatu penyajian materi, yang dilakukan secara sistematis dan terstruktur. Penggunaan multimedia dalam kelas dapat diterima secara umum atas dasar mempertinggi proses belajar mandiri serta peran aktif dari para siswa.

Pengertian multimedia juga dijelaskan oleh Dharma Oetomo (2002, p.109) sebagai berikut:

Secara umum multimedia diartikan seba gai kombinasi teks, gambar, seni grafik, animasi, suara dan video. Aneka media tersebut digabungkan menjadi satu kesatuan kerja yang akan menghasilkan suatu informasi yang memiliki nilai komunikasi yang sangat tinggi; artinya informasi bahkan tidak hanya dapat dilihatsebagai hasil cetakan, melainkan juga dapat didengar, membentuk simulasi dan animasi yang dapat membangkitkan selera dan memiliki nilai seni grafis yang tinggi dalam penyajiannya. 
Suyanto (2005, p.21), menjelaskan bahwa dalam multimedia terkandung empat komponen penting yaitu: (1) komputer yang mengkoordinasikan apa yang dilihat dan didengar, yang berinteraksi dengan kita, (2) harus ada link yang menghubungkan kita dengan informasi, (3) harus ada alat navigasi yang memandu kita, menjelajahjaringan informasi, (4) menyediakan tempat pada kita untuk mengumpulkan, memproses, dan mengkomunikasikan informasi dan ide kita sendiri.

Dari pendapat-pendapat tersebut diatas dapat ditarik kesimpulan bahwa suatu media dapat dikatakan sebagai multimedia jika memenuhi unsur-unsur sebagai berikut: (1) terdiri dari banyak media (teks, grafik, animasi, audio,dan video), (2) media-media yang digunakan terintergrasi dan dikendalikan dalam sebuah program aplikasi komputer, (3) informasi yang disajikan bersifat interaktif dengan pengguna/user, (4) pengguna dapat mengakses setiap sub informasi atau seluruh informasi sesuai yang dibutuhkan.

\section{Peranan Multimedia dalam Pembelajaran}

Perkembangan teknologi komunikasi yang berlangsung begitu pesat telah mengubah cara pandang terhadap proses pembelajaran. Berlangsungnya proses pembelajaran tidak mutlak bergantung kepada tersedianya nara sumber, tempat dan waktu belajar. Ketersediaan beragam media telah memungkinkan proses pembelajaran berlangsung sesuai dengan kebutuhan individu (Budiningsih, 2003, p.30). Komponen media memegang peran penting, dan turut memberi warna pada proses pembelajaran. Lebih lanjut di jelaskan Arsyad (2011, p.15), bahwa fungsi utama media dalam pembelajaran adalah sebagai alat bantu mengajar yang turut mempengaruhi ikim, kondisi, dan lingkungan belajar yang ditata dan diciptakan oleh guru.

Kemp \& Dayton (1985, pp.3-4) mengulas tentang kontribusi media, pada proses pembelajaran adalah sebagai berikut: (1) the delivery if instruction can be more standardized;
(2) the instruction can be more interesting; (3) learning becomes more interactive through applying accepted learning theory; (4) the length of time required for instruction can be reduced; (5) the quality of learning can be improved; (6) the instruction can be provided when and where desired and necessary; (7) the positive attitude of students toward what they are learning and they are learning procces uself can be

Dapat dijelaskan bahwa peranan media dalam proses pembelajaran adalah dapat menjadikan pembelajaran: (1) penyampaian lebih standar; (2) lebih menarik; (3) lebih interaktif; (4) lebih efisien waktu; (5) kualitas pembelajaran dapat ditingkatkan; (6) lebih fleksibel; (7) lebih bermakna dan menye nangkan; (8) meningkatkan peran guru.

Dalam bidang pendidikan, teknologi berbantuan komputer merupakan cara untuk menyampaikan materi dengan menggunakan sumber-sumber yang berbasis mikro komputer, dimana informasi atau materi yang di simpan dalam bentuk digital dan penggunaan teknologi ini selalu terkait dengan penggunaan layar kaca untuk menyajikan informasi atau materi kepada siswa. Materi pelajaran yang sudah terprogram disajikan secara se rempak dengan menggabungkan komponen gambar, tulisan, warna, dan suara. Kelebihan dari multimedia seperti ini menurut Suyanto (2003, p.23) adalah menarik indera dan menarik minat, karena menggabungkan antara penglihatan, gambar, dan suara.

Multimedia pembelajaran merupakan media pembelajaran yang didesain untuk pembelajaran dengan menggunakan banyak indera, karena dalam media tersebut terdapat teks, grafik, images, dan sound (suara), video dan animasi dipadukan dalam kesa tuan yang integral untukpenyampaian pesan pembelajaran. Melalui teknologi komputer multimedia dapat menciptakan komunikasi interaktif dari sebuah informasi, karena mampu mengintegrasikan teks, grafik, suara, animasi, dan video yang mampu mempengaruhi sebanyak mungkin indera yang dimiliki manusia seperti penglihatan, pendengaran, 
dan perasaan. Manusia belajar melalui alat indera yang dimilikinya (Latuheru, pp.1988: 81).

Siswa yang memanfaatkan multimedia dalam proses pembelajarannya, diharapkan dapat mencapai potensi hasil belajarnya secara optimal, secara umum. Sadiman (2011, pp.17-18) menyatakan bahwa media sebagai alat bantu pembelajaran digunakan guru/ pendidik untuk: memperjelas informasi atau pesan pembelajaran; mengatasi keterbatasan ruang, waktu dan daya indera; menim bulkan kegairahan belajar; dan memberi variasi pembelajaran.

Media pembelajaran menjadikan siswa lebih aktif. Pembelajaran tidak hanya terpusat pada guru. Guru bertugas sebagai pembimbing atau mentor dan juga fasilitator. guru dan siswa dapat saling berdiskusi tentang berbagai informasi dan pengalaman untuk memperkaya pengetahuan (Vaughan, 2008, p.6).

Media pembelajaran bagi guru dan siswa menurut Smaldino, Lowther \& Russel (2011, pp.14-17 ) dapat digunakan untuk: mendukung penyajian pengajaran; menyampaikan informasi baru; membantu guru menjadi pengelola kreatif dari pengalaman mengajar, ketimbang sekedar sebagai pembagi informasi dan Teknologi yang dirancang dengan cermat dapat membuat belajar menjadi lebih efektif.

Dari beberapa pendapat diatas, menyatakan bahwa peranan multimedia dalam pembelajaran memberikan nuansa baru untuk membuat suasana pembelajaran menjadi lebih lebih interaktif, efisien, efektif, dan menyenangkan. Multimedia juga dapat digunakan untuk melakukan pembelajaran mandiri maupun kelompok tergantung permasalahan yang harus diselesaikan.

\section{Teori Belajar yang Melandasi pengem- bangan Multimedia}

Munculnya pengembangan multimedia pembelajaran berbantuan komputer tidak bisa lepas dari teori belajar dan teori lain yang melandasinya. Teori-teori tersebut memberikan dasar berpijak dalam membangun suatu pola pikir sistematis dalam pembelajaran, se- hingga produk-produk pengembangan yang dihasilkan akan dapat teraplikasikan dalam pembelajaran secara optimal.

Menurut Driscoll, (2000), pembelajaran yang menggunakan media, dapat ditinjau dengan 4 perspektif pada teori pembelajaran, yakni Behaviorist perspective, cognitive perspective, constructivist perspective and social-psichological perspective.

\section{Behavioristik Perspektif}

Menurut teori behavioristik, belajar adalah perubahan tingkah laku sebagai akibat dari adanya interaksi antara stimulus dan respon. Dengan kata lain, belajar merupakan bentuk perubahan yang dialami siswa dalam hal kemampuanya untuk bertingkah laku dengan cara yang baru sebagai hasil interaksi antara stimulus dan respon. Seseorang dianggap sudah belajar sesuatu jika ia dapat menunjukkan perubahan tingkah lakunya (Smaldino, 2012, p.51).

Menurut teori ini yang terpenting adalah masukan atau input yang berupa stimulus dan keluaran atau output yang berupa respons. Menurut teori behavioristik apa yang terjadi diantara stimulus dan respon dianggap tidak penting diperhatikan karena tidak dapat diamati dan tidak dapat diukur. faktor lain yang dianggap penting oleh aliran beha vioristik adalah faktor penguatan (reinforcement). Pengetahuan adalah apa yang dapat memperkuat timbulnya respon. Bila pengetahuan ditambahkan (positive reinforcement) maka respon akan semakin kuat. Begitu juga ketika penguatan dikurangi (negative reinforcement) responpun akan tetap dikuatkan (Budiningsih, 2005, p. 20).

\section{Kognitif Perspektif}

Teori belajar kognitif lebih mementingkan proses belajar daripada hasil belajarnya. Teori ini mengajukan istilah metakognisi yang merujuk pada pengetahuan dan pemikiran mengenai proses berpikir seseorang, seperti cara menyelesaikan masalah dan mengambil keputusan (Smaldino, 2012, p.53).

Teori kognitif juga menekankan bahwa bagian-bagian dari suatu situasi saling berhubungan dengan seluruh konteks situasi 
tersebut. Memisahkan dan membagi materi pelajaran menjadi komponen-komponen yang kecil dan mempelajarinya secara terpisah akan kehilangan makna. Teori ini berpandangan bahwa belajar merupakan suatu proses internal yang mencakup ingatan, retensi, pengolahan informasi, emosi dan aspek-aspek kejiwaan lainnya (Budiningsih, 2005, p.34).

\section{Kontruktivistik Perspektif}

Proses belajar diartikan sebagai pemberian makna oleh siswa kepada pengalamannya melalui proses asimilasi dan akomodasi yang bermuara pada pemutakhiran struktur kognitifnya. Pemberian makna terhadap objek dan pengalaman oleh individu tersebut tidak dilakukan secara sendiri-sendiri oleh siswa melainkan melalui interaksi dalam jaringan sosial yang unik, yang terbentuk baik dalam budaya kelas maupun di dalam kelas. Oleh sebeb itu pengolahan pembelajaran harus diutamakan pada pengelolaan siswa dan lingkungan belajarnya bahkan pada unjuk kerja atau prestasi belajarnya yang dikaitkan dengan sistem penghargaan dari luar seperti nilai ijasah dan sebagainya (Budiningsih, 2005, p.58).

Konstruktivistik mengakibatkan siswa lebih aktif dan kreatif. Pembelajaran berpusat pada siswa (student center) dan penanaman konsep ditekankan pada pemecahan masalah dan penemuan aktif (Smaldino, 2012, pp.13-14).

\section{Perspektif Psikologi Sosial}

Teori ini memusatkan efek organisasi sosial dalam ruang kelas terhadap belajar. Menurut Slavin belajar kooperatif lebih efektif dan menguntungkan dibandingkan belajar kompetitif dan individual (Smaldino, 2012, p.14).

\section{METODE}

Jenis penelitian ini termasuk penelitian dan pengembangan atau Research and Development (R\&D). Model pengembangan yang digunakan dalam penelitian ini, menggunakan perpaduan model pengembangan dari Borg \& Gall (1983, p.572) dan Dick \& Carey (2005, pp.6-8). Hal ini dilakukan agar lebih sederhana dan mudah dipahami. Model pengembangan hasil perpaduan tersebut memiliki lima tahap sebagai berikut.

Analisis: pada tahap ini kegiatan yang dilakukan adalah menganalisis kebutuhan dan karakteristik siswa, menganalisis kurikulum untuk mendapatkan kompetensi hasil belajar, memilih dan menetapkan materi pokok yang akan dikembangkan, dan mengembangkan alat evaluasi. (a)Menetapkan materi pokok: Menetapkan SK, KD dan materi litosfer dan pedosfer. (b) Desain: pada tahap ini membuat storyboard dan flowchart. (c)Produksi: pada tahap ini dilakukan pengemasan materi ke dalam CD sesuai storyboard yang telah dibuat. (d) Pengemasan produk awal: Pengemasan produk awal dalam bentuk Compact Disk (CD) pembelajaran untuk di uji cobakan. (e) Uji coba dan revisi: sebelum uji coba dilaksanakan, dilaksanakan review oleh ahli materi dan ahli media terhadap produk multimedia yang dikembangkan. Kemudian dilakukan uji coba dengan langkah-langkah sebagai berikut: Uji coba satu-satu, yang dilakukan terhadap 3 orang siswa; Uji coba kelompok kecil, yang dilakukan terhadap 12 orang siswa; Uji coba kelompok besar/ uji coba lapangan, yang dilakukan terhadap 20 orang siswa. Revisi dilakukan setiap selesai melakukan uji coba yang berdasarkan saran dan kritik dari subjek coba. (a) Produk akhir: pada tahap ini setelah melakukan uji coba dan revisi dilakukan pembuatan produk akhir dari multimedia hasil pengembangan. Pengumpulan data menggunakan instrumen berupa angket dan dokumentasi hasil belajar siswa. Instrumen yang akan digunakan, sebelumnya telah diuji validitas dan reliabilitasnya. Teknik analisis data yang digunakan dalam penelitian ini adalah teknik deskriptif kualitatif karena data yang diperoleh berupa data kualitatif dan kuantitatif. Data tersebut berupa: 1. Data dari instrument angket penelitian, lembar observasi, dan pedoman wawancara dianalisis dengan statistik deskriptif kualitatif. 2. Data yang diperoleh melalui angket merupakan tanggapan dari siswa, ahli materi, dan ahli media, dibandingkan dengan 
skor ideal pada skala 5 .

Data yang didapat terlebih dahulu dikonversi menjadi data interval dengan ketentuan sebagai berikut:
Sangat Baik
$(\mathrm{SB})=5$
Baik
(B) $=4$
Cukup
(C) $=3$
Kurang
$(\mathrm{K})=2$
Sangat Kurang $(\mathrm{SK})=1$
Dari Penilaian Acuan Patokan di atas di- peroleh pedoman konversi data kuantitatif ke kualitatif sebagai berikut:

Tabel 6.

Pedoman Konversi Data Kuantitatif ke Data Kualitatif

\begin{tabular}{ccc}
\hline Nilai & Internal Perhitungan & Kriteria \\
\hline A & $\mathrm{X}>4,21$ & Sangat Baik \\
B & $3,40<\mathrm{X} \leq 4,21$ & Baik \\
C & $2,60<\mathrm{X} \leq 3,40$ & Cukup \\
D & $1,79<\mathrm{X} \leq 2,60$ & Kurang \\
E & $\mathrm{X} \leq 1,79$ & Sangat Kurang \\
\hline
\end{tabular}

Dalam penelitian ini, ditetapkan nilai kelayakan produk minimal $\mathrm{C}$, dengan kategori cukup, sebagai hasil penilaian baik dari ahli materi dan siswa. Jika hasil penilaian akhir (keseluruhan) pada aspek materi dan bahan ajar yang dikembangkan dengan nilai minimal C (cukup) oleh para ahli, dan jika hasil penilaian akhir (keseluruhan) dangan nilai minimal C (cukup) oleh siswa, maka produk hasil pengembangan tersebut sudah dianggap layak digunakan oleh siswa dalam pembelajaran.

Untuk mencari skor rata-rata (rerata skor) dalam memberikan penilaian terhadap produk yang telah dikembangkan digunakan rumus:

$$
\bar{x}_{i}=\frac{\sum x}{n}
$$

Keterangan :

$\bar{x}_{i}$ : Skor rata-rata

$\sum x$ : Jumlah Skor

$n$ : Jumlah responden

\section{HASIL DAN PEMBAHASAN}

Analisis Data Hasil Penilaian Ahli Analisis Data Hasil Validasi Ahli Materi

Berdasarkan data yang diperoleh dari hasil evaluasi oleh ahli materi dapat dianalisis dan dijadikan sebagai acuan untuk merevisi produk pembelajaran yang dikembangkan. Data tersebut meliputi 6 aspek, yaitu aspek 
relevasi materi, aspek kekuratan materi, aspek kelengkapan sajian materi, aspek sistematika sajian materi, aspek kesesuaian sajian dengan tuntutan pembelajaran yang berpusat pada siswa, aspek cara penyajian materi.

Aspek relevansi materi sebanyak 8 butir indikator. Sebagaimana yang terdapat pada tabel 4 , skor rerata pada relevansi materi sebesar 4,00. Angka tersebut masuk dalam kriteria "baik". Indikator yang dinilai baik adalah: (1) Relevansi materi dengan kompetensi yang harus dikuasai siswa; (2) Relevansi contoh-contoh penjelasan dengan kompetensi yang harus dikuasai siswa; (3) Relevansi latihan dan soal dengan kompetensi yang harus dikuasai siswa; (4) Relevansi kedalaman uraian dengan kompetensi yang harus dikuasai siswa; (5) Kelengkapan uraian materi sesuai dengan tingkat perkembangan; (6) Jabaran materi cukup memenuhi tuntutan kurikulum; (7) Kecukupan fungsi ilustrasi; (8) Kecukupan jumlah latihan, soal dan tugas.

Aspek keakuratan materi sebanyak 4 (empat) indikator penilaian, Sebagaimana yang terdapat pada tabel 5 , skor rerata pada aspek keakuratan materi adalah 4,25. Angka tersebut masuk dalam kriteria "baik". Pada aspek ini, terdapat 1 indikator yang dinilai sangat baik yaitu indikator kesesuaian materi yang diberikan dengan kehidupan seharihari, dan indikator-indikator yang dinilai baik adalah: (1) Kesesuaian materi dengan kebenaran ilmu; (2) Kesesuaian materi yang diberikan dengan perkembangan mutakhir; (4) Kesesuaian pengemasan materi dengan pendekatan keilmuan yang bersangkutan.

Aspek kelengkapan sajian terdiri atas 4 (empat) indikator. Sebagaimana yang terdapat pada tabel 6, maka skor rerata dari penilaian ahli materi terhadap produk yang dikembangkan sebesar 4,00. Angka tersebut masuk dalam kriteria "baik". Adapun rincian dari 4 indikator tersebut adalah: (1) Sajian kompetensi yang harus dikuasi siswa; (2) Sajian manfaat dan pentingnya penguasaan kompetensi bagi kehidupan siswa; (3) Sajian dafar isi; (5) Sajian daftar Pustaka.

Aspek sistematika sajian sebanyak 2 indikator penilaian. Sebagaimana yang ter- dapat pada tabel 7, maka skor rerata dari penilaian ahli materi terhadap produk yang dikembangkan sebesar 4,00. Angka tersebut masuk dalam kriteria "baik". Pada aspek ini semua indikator masuk dalam kriteria baik. Adapun rincian dari 2 indikator tersebut adalah: uraian materi mengikuti alur pikir dari sederhana ke kompleks.dan uraian materi mengikuti alur pikir dari lingkup lokal ke global.

Aspek kesesuaian sajian dengan tuntutan pembelajaran yang berpusat pada siswa sebanyak 4 indikator penilaian. Sebagaimana yang terdapat pada tabel 8 , maka skor rerata dari penilaian ahli materi terhadap produk yang dikembangkan sebesar 3,75. Angka tersebut masuk dalam kriteria "baik". Pada aspek ini ada satu indikator yang dinilai cukup yaitu pada indikator mendorong siswa belajar secara berkelompok. Adapun rincian dari 3 indikator-indikator yang dinilai baik adalah: Mendorong terjadinya interaksi siswa dengan sumber belajar; Mendorong rasa keingin tahuan siswa; dan Mendorong siswa untuk mengamalkan isi bacaan.

Aspek cara penyajian materi sebanyak 8 indikator. Sebagaimana yang terdapat pada tabel 9, maka skor rerata dari penilaian ahli materi terhadap produk yang dikembangkan sebesar 4,00. Angka tersebut masuk dalam kriteria "baik". Pada aspek ini semua indikator masuk dalam kriteria baik. Adapun rincian dari 8 indikator tersebut yaitu: Mendukung pertumbuhan nilai-nilai kemanusiaan; Mendukung cara berpikir logis siswa; Kesesuaian bahasa yang digunakan dengan kaidah bahasa Indonesia; Keterbacaan; Ketepatan penggunaan struktur kalimat; Ketepatan penggunaan ejaan; Ketepatan penggunaan istilah; Struktur kalimat sesuai dengan pemahaman siswa.

Secara umum validasi ahli materi terhadap multimedia yang dikembangkan adalah "baik", namun masih ada beberapa saran dan komentar yang diberikan oleh ahli materi untuk merevisi produk guna meningkatkan kualitas produk yang dikembangkan. Ahli matri memberikan saran dan komentar sebagai berikut: " gambar lebih di perbanyak lagi". 


\section{Analisis Data Hasil Penilaian Ahli Media}

Data yang diperoleh daria ahli media terdiri dari 15 indikator. Hasil dari penilaian yang diperoleh dari ahli media untuk pengembangan sumber dan media pembelajaran di ketahui bahwa skor rerata adalah 4,07. Angka tersebut masuk dalam kriteria "baik". Pada penilaian ini, terdapat 1 indikator yang dinialai sangat baik dan 14 indikator masuk dalam katagori baik. Adapun indikator yang dinilai sangat baik adalah indikator kesesuaian media dengan tujuan pembelajaran yang akan di capai, dan indikator yang dinilai baik adalah: (1) Kemampuan media dalam membangkitkan motivasi belajar; (2) Kemampuan media dalam mengaktifkan siswa; (3) Kemampuan media dalam menciptakan rasa senang siswa dalam belajar; (4) Kemampuan media dalam menjadikan siswa kreatif; (5) Kemampuan media sebagai stimulus belajar; (6) Kesesuaian media dengan karakter siswa; (7) Kesesuaian media untuk umpan balik; (8) Kesesuaian media dengan lingkungan belajar. (9) Efisiensi penggunaan media dalam kaitanya dengan waktu; (10) Efisiensi penggunaan media dalam kaitannya dengan biaya; (11) Kemampuan media untuk mengaktifkan siswa; (12) Kualitas bahan media; (13) Kualitas statistik media; (14) Sisi keamanan media bagi siswa.

Hasil evaluasi dari ahli media menunjukkan bahwa pengembangan multimedia pembelajaran adalah "baik", namun masih ada beberapa saran dan masukan yang berikan oleh ahli media untuk merevisi produk guna lebih meningkatkan kualitas produk yang dikembangkan.

\section{Analisis Data Hasil One to One Evaluation}

Data yang diperoleh dari hasil uji coba one to one evaluation meliputi data kualitas media yang dilihat dari 3 aspek, yaitu aspek kemudahan produk multimedia untuk dioperasikan, aspek kemudahan produk untuk dipelajari isinya, dan aspek kemenarikan tampilan. Data ini dikaji untuk mendapatkan bukti-bukti empiris tentang kelayakan produk, mengidentifikasi kesalahan-kesalahan dan untuk mendapatkan revisi dan komentar saran terhadap produk. Dalam uji coba ini jumlah siswa yang memberikan tanggapan terhadap media yang dikembangkan adalah sebanyak 3 orang siswa.

\section{Aspek Kemudahan Produk untuk Diop- erasikan}

Secara umum, data hasil validasi pada uji coba one to one evaluation pada aspek kemudahan produk untuk dioperasikan menunjukkan bahwa skor rerata yang diperoleh adalah 3,60 , angka ini masuk dalam kriteria "baik". Secara rinci terdapat 7 indikator yang dinilai baik, dan 3 indikator yang dinilai cukup. Adapun indikator yang dinilai baik adalah: Kejelasan petunjuk penggunaan produk; Kemudahan memulai program; Kemudahan mengakhiri; Kemudahan memilih menu program; Tingkat kemudahan menggunakan program; Kemudahan petunjuk mengerjakan soal tes; Kebebasan memilih menu program. Rincian 3 indikator yang dinilai cukup adalah: Kemudahan menggunakan tombol; Konsistensi tata letak tombol; Navigasi yang digunakan untuk memudahkan anda menggunakan media.

\section{Aspek Kemudahan Produk untuk Dipela- jari Isinya}

Secara umum, data hasil validasi pada uji coba one to one evaluation pada aspek kemudahan produk untuk dipelajari isinya menunjukkan bahwa skor rerata yang diperoleh adalah 3,76, angka ini masuk dalam kriteria "baik". Secara rinci terdapat 8 indikator yang dinilai baik, dan 2 indikator yang dinilai cukup. Adapun indikator yang dinilai baik adalah: Kejelasan rumusan kompetensi dasar; Kejelasan indikator keberhasilan; Kejelasan uraian materi untuk anda pelajari; Ketepatan urutan penyajian materi; Penyampaian materi menarik bagi anda; Penggunaan teks dan gaya bahasa yang mendukung pemahaman anda terhadap materi; Keterbacaan teks; Penggunaan gambar, foto dan animasi mendukung pembelajaran dan pemahaman anda terhadap materi. Rincian 2 indikator yang dianggap baik adalah: Pemberian contoh mendukung pemahaman anda 
terhadap materi; Kejelasan butir soal latihan untuk anda kerjakan.

\section{Aspek Kemenarikan Tampilan}

Secara umum, data hasil validasi pada uji coba one to one evaluation pada aspek kemenarikan tampilan menunjukkan bahwa skor rerata yang diperoleh adalah 3,54, angka ini masuk dalam kriteria "baik". Secara rinci terdapat 6 indikator yang dinilai baik, dan 5 indikator yang dinilai cukup. Adapun indikator yang dinilai baik adalah: Kemenarikan desain latar produk; Ketepatan tata latak teks; Kese rasian dan kemenarikan pilihan jenis huruf, ukuran huruf, dan spasi tulisan; Kesesuaian latar dengan warna huruf; Kesesuaian penggunaan gambar/foto; Keserasian dan kese imbangan antara teks dengan video. Rincian 2 indikator yang dianggap cukup adalah: Keserasian dan keseimbangan tampilan teks, Kemenarikan warna latar produk; Keserasian dan kemenerikan tombol produk; Kesesuaian penggunaan video; Ketepatan penggunaan video dan audio.

Analisis Data Hasil Small Group Evaluation

Uji coba small group evaluation digunakan untuk menguji coba multimedia setelah direvisi dan dianalisis berdasarkan uji coba sebelumnya yaitu uji coba one to one. Pada tahap ini mengidentifikasi permasalahan yang masih ditemui dalam produk yang dikembangkan sebelumnya. Data dikaji untuk mengetahui tanggapan siswa terhadap produk yang dikembangkan sebelum produk tersebut dikembangkan pada uji coba kelompok besar (field trial evaluation). Pada tahap uji coba small group evaluation sebanyak 12 orang memberikan tanggapan.

\section{Aspek Kemudahan Produk untuk Diop- erasikan}

Secara umum pada aspek kemudahan produk untuk dioperasikan, skor rerata penilaian siswa adalah 3,58 , angka ini masuk dalam kriteria "baik". Secara rinci terdapat 8 indikator yang dinilai baik, dan 2 indikator yang dinilai sangat baik. Adapun indikator yang dinilai baik adalah: Kejelasan petunjuk penggunaan produk; Kemudahan memilih menu program; Kemudahan menggunakan tombol; Konsistensi tata letak tombol; Tingkat kemudahan menggunaakan program; Kemudahan petunjuk mengerjakan soal tes; Kebebasan memilih menu program; Navigasi yang digunakan untuk memudahkan anda. Rincian 2 indikator yang dinilai sangat baik, yaitu: Kemudahan memulai program; Kemudahan mengakhiri.

\section{Aspek Kemudahan Produk untuk Dipela- jari Isinya}

Secara umum kemudahan produk untuk dipelajari isinya, skor rerata penilaian siswa adalah 3,85, angka ini masuk dalam kriteria "baik". Pada aspek kemudahan produk untuk dioperasikan terdapat 10 indikator, yang semuanya dinilai baik. Adapun 10 indikator yang dinilai baik tersebut adalah: Kejelasan rumusan kompetensi dasar; Kejelasan indikator keberhasilan; Kejelasan uraian materi untuk anda pelajari; Ketepatan urutan penyajian materi; Penyampaian materi menarik bagi anda; Penggunaan teks dan gaya bahasa yang mendukung pemahaman anda terhadap materi; Keterbacaan teks; Pemberian contoh mendukung pemahaman anda terhadap materi; Kejelasan butir soal latihan untuk anda kerjakan; Penggunaangambar, foto dan animasi mendukung pembelajaran dan pemahaman anda terhadap materi.

\section{Aspek Kemenarikan Tampilan}

Secara umum aspek kemenarikan tampilan, skor rerata penilaian siswa yang diperoleh adalah 3,80, angka ini masuk dalam kriteria "baik". Pada aspek kemenarikan tampilan terdapat 10 indikator, yang semuanya dinilai baik. Adapun 10 indikator yang dinilai baik tersebut adalah: Keserasian dan keseimba-ngan tampilan teks; Kemenarikan warna latar produk;Kemenarikan desain latar produk; Keserasian dan kemena rikan tombol produk; Ketepatan tata latak teks; Keserasian dan kemenarikan pilihan jenis huruf, ukuran huruf, dan spasi tulisan; Kesesuaian latar dengan warna huruf; Kesesuaian penggunaan video; Kesesuaian penggunaan gambar/foto; Keserasian dan keseimbangan antara teks dengan video. 
Analisis Data Hasil Field Trial Evaluation

Tujuan uji coba lapangan (Field Trial Evaluation) adalah untuk menentukan apakah produk yang dihasilkan sudah memiliki kelayakan dilihat dari sudut pandang siswa, aspek yang dilihat oleh siswa yaitu aspek kemudahan produk untuk dioperasikan, aspek kemudahan produk untuk dipelajari isinya dan aspek kemenarikan tampilan. Pada tahap field trial evaluation 20 siswa memeberikan penilaian produk.

\section{Aspek Kemudahan Produk Untuk Diop- erasikan}

Pada aspek kemudahan produk untuk dioperasikan, skor rerata yang diperoleh adalah 3,58 , hal ini secara umum, produk multimedia yang dikembangkan termasuk criteria "baik". Pada aspek kemdahan produk untuk dioperasikan, secara rinci terdapat 8 indikator yang dinilai baik dan 2 indikator yang dinilai cukup. Rincian 8 indikator yang dinilai baik adalah: Kemudahan memulai program; Kemudahan mengakhiri; Kemudahan memilih menu program; Kemudahan menggunakan tombol; Konsistensi tata letak tombol; Tingkat kemudahan menggunakan program; Kemudahan petunjuk mengerjakan soal tes; Navigasi yang digunakan untuk memudahkan anda. Rincian 2 indikator yang dinilai cukup adalah: Kejelasan petunjuk penggunaan produk; Kebebasan memilih menu program.

\section{Aspek Kemudahan Produk untuk dipela- jari Isinya}

Pada aspek kemudahan produk untuk dipelajari isinya, skor rerata yang diperoleh adalah 3,25, hal ini secara umum, produk multimedia yang dikembangkan termasuk kriteria "baik". Pada aspek kemudahan produk untuk dipelajari isinya, secara rinci terdapat 7 indikator yang dinilai baik dan 3 indikator yang dinilai cukup. Rincian 7 indikator yang dinilai baik adalah: Kejelasan rumusan kompetensi dasar; Ketepatan urutan penyajian materi; Penyampaian materi menarik bagi anda; Penggunaan teks dan gaya bahasa yang mendukung pemahaman anda terhadap materi; Keterbacaan teks; Kejelasan butir soal latihan untuk anda kerjakan; Penggunaangambar, foto dan animasi mendukung pembelajaran dan pemahaman anda terhadap materi. Rincian 3 indikator yang dinilai cukup adalah: Kejelasan indikator keberhasilan; Kejelasan uraian materi untuk anda pelajari; Pemberian contoh mendukung pemahaman anda terhadap materi.

\section{Aspek Kemenarikan Tampilan}

Pada aspek kemenarikan tampilan, skor rerata yang diperoleh adalah 3,86, hal ini secara umum, produk multimedia yang dikembangkan termasuk kriteria "baik". Analisis penilaian siswa pada aspek kemenarikan tampilan terdapat 11 indikator, yang semuanya dinilai baik. Adapun 11 indikator yang dinilai baik tersebut adalah: Keserasian dan keseimbangan tampilan teks; Kemenarikan warna latar produk; Kemenarikan desain latar produk; Keserasian dan kemenarikan tombol produk; Ketepatan tata latak teks; Keserasian dan kemenarikan pilihan jenis huruf, ukuran huruf, dan spasi tulisan; Kesesuaian latar dengan warna huruf; Kesesuaian penggunaan video; Kesesuaian penggunaan gambar/foto; Keserasian dan keseimbangan antara teks dengan video; Ketepatan penggunaan video dan audio.

\section{Analisis Data Pretest-Postest Hasil Belajar Geografi}

Untuk mengetahui ada tidaknya perubahan pengetahuan siswa setelah mempelajari materi litosfer dan pedosfer menggunakan media pembelajaran yang dikembangkan, data hasil pretest dan posttest dibandingkan. Data tersebut dianalisis secara deskriptif kuantitatif seperti yang tersaji pada tabel 1 berikut: 
Tabel 1:

Kenaikan Hasil Belajar Geografi Pada Saat Pretest dan Posttest

\begin{tabular}{lcccl}
\hline \multicolumn{1}{c}{ Diskripsi } & \multicolumn{2}{c}{ Nilai } & Selisih & Keterangan \\
\hline & Pretest & Postest & & \\
\hline Mean & 78,75 & 88,50 & 9,75 & Meningkat \\
Median & 80,00 & 90,00 & 10 & Meningkat \\
Modus & 80,00 & 90,00 & 10 & Meningkat \\
Nilai Maksimum & 85,00 & 95,00 & 10 & Meningkat \\
Nilai Minimum & 70,00 & 80,00 & 10 & Meningkat \\
\hline
\end{tabular}

Berdasarkan tabel 34 di atas, terdapat peningkatan pada pilihan jawaban dalam bentuk skor mean pretest 78,75 dan mean posttest menjadi 88,50 terjadi peningkatan sebesar 9,75. Pada skor median pretest yaitu 80,00 dan median posttest menjadi 90,00 sehingga meningkat sebesar 10 . Untuk skor modus pretest yaitu sebesar 80,00 dan modus posttest 90,00 sehingga meningkat sebesar 10. Adapun nilai maksimum yang diperoleh pada pretest yaitu 85,00 menjadi 95,00 sehingga meningkat sebesar 10 . Sedangkan nilai minimum yang diperoleh pada saat pretest yaitu 70,00 menjadi 80,00 sehingga menigkat 10. Hal ini menunjukkan bahwa multimedia pembelajaran geografi materi litosfer dan pedosfer untuk SMA kelas X secara efektif dapat meningkatkan hasil belajar siswa.

\section{SIMPULAN}

Multimedia pembelajaran geografi materi litosfer dan pedosfer untuk SMA kelas X telah berhasil dikembangkan dan di kemas dalam bentuk Compack Disk (CD) pembelajaran interaktif. Multimedia pembelajaran geografi materi litosfer dan pedosfer memiliki kualitas yang baik sehingga efektif dipergunakan untuk meningkatkan hasil belajar siswa. Hal ini dibuktikan dengan hasil perbandingan pretest dan posttest. Untuk hasil belajar geografi nilai rata-rata siswa pada saat pretest adalah sebesar 78,75 , sedangkan pada posttest nilai rata-rata yang dicapai oleh siswa adalah 88,50. Persentase peningkatan ketuntasan hasil belajar siswa adalah sebesar $10 \%$.

Berdasarkan simpulan tersebut maka dapat disampaikan saran-saran sebagai berikut. Saran Bagi guru yaitu produk multimedia pembelajaran ini sebaiknya digunakan oleh guru sebagai alat bantu pembelajaran geografi pada materi litosfer dan pedosfer di kelas X. Bagi Siswa produk multimedia ini dapat digunakan secara mandiri agar hasil lebih maksimal. Sekolah juga diharapkan dapat menyebarluaskan produk ini kepada guru-guru pada saat pertemuan MGMP (Musyawarah Guru Mata Pelajaran) geografi atau melalui pameran pendidikan. Selain itu, multimedia pembelajaran geografi materi litosfer dan pedosfer ini masih pada taraf pemula sehingga perlu dikembangkan lebih lanjut, dengan memperbaiki kualitas produk dari aspek isi dan tampilan desain multimedia.

\section{UCAPAN TERIMA KASIH}

Dalam penulisan artikel jurnal ini, penulis sangat dibantu oleh banyak pihak khususnya dosen pembimbing. Untuk itu, dalam kesempatan ini penulis menyampaikan terima kasih kepada yang terhormat Pembimbing tesis, yang telah banyak membantu, mengarahkan dan membimbing sehingga artikel jurnal ini dapat terselesaikan. 


\section{DAFTAR PUSTAKA}

Arief, S. Sardiman, dkk. 2011. Media Pendidikan: Pengertian Pengembangan, Dan Pemanfaatanya. Jakarta: PT. Raja Grafindo Perkasa.

Budiningsih C, Asri, . 2003. Desain Pesan Pembelajaran. Yogyakarta: Fakultas Ilmu Pendidikan Universitas Negeri Yogyakarta.

Arsyad, Azhar. 2011. Media Pembelajaran. Jakarta: PT. Raja Grafindo Persada.

----------. 2005. Belajar dan Pembelajaran. Jakarta: PT. Rinneka Cipta.

Ball John. M., et.al. 1971. The Social Sciences And Geographic Education: A Reader. Canada: John Wiley \& Sons, Inc.

Barlet, L. \& Bernard Cox. 1982. Learning To Teach Geography. New York: John Wiley \& Sons.

Borg. W. R \& Gall. M. D. 1983. Educational Research: An Introduction. Fourth edition. New York: Longman Inc.

----.--. 2003. Educational Research. New York: Von Hoffman Press, Inc.

Oetomo, Dharma, dan Budi Soetejo. 2002. Eeducational Konsep Teknologi Dan Aplikasi Internet Pendidikan. Yogyakarta: Andi Press.

Yudhiantoro, Dhani. 2003. Panduan Lengkap Macromedia Flash Mx . Yogyakarta: Andi Offset.

Dick, W. \& Carey, L. 2005. The Systematic Design of Instruction. New York: Harper-Collins

.Widyoko, Eko Putro. 2010. Evaluasi Program Pembelajaran. Yogyakarta: Pustaka Pelajar

Uno, Hamzah B. 2011. Perencanaan Pembelajaran. Jakarta: Bumi Aksara.

Istirokhah. 2010. Pengembangan Multimedia Berbasis Komputer Untuk Pendidikan Kewarganegaraan Siswa Madrasah Aliyah". Tesis Magister, Tidak Diterbitkan. Pasacarjana UNY.

Kemp, J. E. \& Dayton, D. K. 1985. Planning And Producing Instructional Media. New York: Harper \& Row Publisher.

Kulik, Bangert, Williams 2002. Electronic Jurnal For The Integration Of Technology In Education Vol 1 No. 2. Diunduh Tanggal 24 November 2011 dari http://ejite.isu.edu/ Volume 1 No.2/jenks.pdf.htm

Lange, O., Ivanova, M. \& Lebedeva, N. 1985. Geologi Umum. Jakarta: Gaya Media Pratama.

Latuheru, John D. 1988. Media Pembelajaran Dalam Proses Belajar Mengajar Masa Kini.
Jakarta: Departemen Pendidikan dan Kebudayaan.

Mayer, R.E. 2009. Multimedia Learning. Surabaya: ITS Press.

Darmawidjaja, M. Isa .1992. Klasifikasi Tanah. Yogyakarta: Gadjah Mada University Press.

Sudjana, Nana. 2000. Dasar-Dasar Proses Belajar Mengajar. Bandung: Sinar Baru Algensindo.

Sumaatmaja, Nursid. 1988. Studi Geografi: Suatu Pendekatan Dan Analisa Keruangan. Bandung: Alumni.

Hamalik, Oemar. 2004. Psikologi Belajar Mengajar. Bandung: Sinar Baru Algensindo.

Sardiman, A. M. 2011. Interaksi \& Motivasi Belajar Mengajar. Jakarta: PT. Raja Grafindo Persada.

Siddiqui, M. H. 2004. Teaching Of Geography. New Delphi: A.P.H Publishing Corporation.

Smaldino, S. E., Lowther, D. L. \& Russell J.D. 2011. Instructional Technology And Media For Learning: Teknologi Pembelajaran Dan Media Untuk Belajar. Jakarta: Kencana Prenada Media Group.

Suyanto. 2005. Multimedia Alat Untuk Meningkatkan Keunggulan Bersaing. Yogyakarta: Andi Offset.

Wahyono, Teguh. 2006. Animasi Dengan Macromedia Flash 8. Jakarta: Elex Media Komputindo

Krisnawati, Titik. 2010. Pengembangan Multimedia Pembelajaran Untuk Mata Pelajaran Biologi Di SMP. Tesis Magister, Tidak Diterbitkan. Pascasarjana UNY.

Undang-Undang Nomor 20 Tahun 2003, Tentang Sistem Pendidikan Nasional.

Wati, Unik Ambar. 2010. Pengembangan Multimedia Pembelajaran Tematik Untuk Mahasiswa PGSD FIP UNY. Laporan Penelitian. UNY.

Vaughan, Tay. 2008. Multimedia: Making It Work. Yogyakarta: Penerbit Andi.

Wagiran. 2008. Pengembangan Media Pembelajaran Berbantuan Komputer Dalam Mendukung Perkuliahan Metrologi. Jurnal Kependidikan Volume 38, Nomor 2 November.

Williams, M. 1976. Geography And The Integrated Curriculum. London: Heinemann Educational Books.

Yuriani, Endang Mulyatiningsih \& Haryanto. 2005. Pengembangan Media Pembelajaran CD Interaktif Mata Kuliah Kontinental. Jurnal Penelitian Saintek, Volume 10, Nomor 2. 